\title{
East Europe's reactors in trouble
}

AN international study of the basic design faults of more than 20 ageing Soviet-built pressurized water reactors in Eastern Europe has given rise to great concern about safety.

The state of the nuclear power industry of that vulnerable and densely populated region has now been reviewed in a scientific programme mounted by the International Atomic Energy Agency (IAEA). The study identified more than 1,000 specific problems arising from weaknesses that could lead to disaster.

The study was part of a larger survey of 62 largely obsolete Soviet-designed nuclear power plants, most of them in Europe. "It is absolutely necessary," a specialist IAEA spokesman emphasizes in diplomatic language barely masking the alarm caused by the findings, "that the safety concerns should be addressed with reasonable economic means and within an acceptable time frame." One result of the expert report is that Western nuclearenergy companies, much of whose business may have been lost after the Chernobyl disaster in the former Soviet Union, may expect a steady flow of orders from Eastern Europe for grafting new technology onto old reactors in order to prolong their working lives in relative safety.

The outcome of the review was discussed at the end of last year at a private meeting at Vienna attended by specialists from the IAEA member states. They concluded that nuclear power would continue to play a dominant role in Eastern Europe because of the dependence of its industries on imported fossil energy as well as degradation of the environment.

The study described some strengths and the many drawbacks of the WWER 440/230 design concept. (The Chernobyl reactor that malfunctioned was a watercooled graphite-moderated design known as RKB 1000). It identified basic weaknesses caused by inadequacies of instrumentation and control as well as electric power supply. The review also complained that the WWER designers had carried out analyses of only a narrow spectrum of potential accidents.

The embrittlement of pressure vessels has given cause for particular concern. So have the quality and practice of operation and maintenance activities, protection against external hazards and fires. The investigators fear that the problems of developing the proper attitude to safety and quality essential for running a potentially dangerous industry may well prove difficult - although not as expensive as the essential technical improvements that must be undertaken.

One logical conclusion of the study is that acute and potentially disastrous weaknesses at other reactors are probably still waiting to be identified. (A separate, confidential report drawn up by the US Central Intelligence Agency considers that at least four reactors in the former Soviet Union are functioning in safety conditions even worse than those prevailing at Chernobyl before the accident there.)

But the experts also agreed that recent political changes and the recent combined work of the IAEA, the European Communities, the Organization for Economic Cooperation and Development, the Nuclear Energy Agency and the World Association of Nuclear Operators, as well as a large number of bilateral efforts, had created the conditions for large-scale cooperation essential for the task at hand.

A basic design fault of the WWER model is held responsible for a near meltdown in 1975 at a four-unit 1,700 MW reactor complex at the Baltic Sea town of Greifswald, in the former East Germany. The incident became known only after the publication of East German state secrets. It seems that a disaster perhaps comparable to that at Chernobyl was narrowly averted when fire cut off power to 11 of the 12 cooling pumps serving one of the reactors at the plant.

Spares from the condemned Greifswald plant are destined for Kozloduy in northern Bulgaria, two of whose still-functioning reactors are reckoned to be 1,000 times more likely to cause a devastating disaster than their modern equivalents in the West. The Bulgarian plant operators understand the risk, but told the Vienna meeting they they cannot afford to close the reactors for lack of alternative energy supplies.

Thomas Land

\section{NIH staffer finds warm reception on other side}

\section{Washington}

ON the morning of 1 August, 1991 Jules Hallum, the director of the National Institute of Health (NIH) scientific misconduct office, and his deputy, Clyde Watkins, headed into Washington for what they knew would be a grim ordeal: a grilling by the staff investigators of Representative John Dingell (Democrat, Michigan).

But what promised to be a unsettling encounter turned out to be even worse. When the two officials arrived, they found themselves across the table from Suzanne Hadley, who had resigned as deputy director of Hallum's Office of Scientific Integrity (OSI) several months earlier. All morning, Hadley and the Dingell staff interrogated Hallum and Watkins about their misconduct policies. Doubly vexing for the two NIH officials was the fact that their former colleague was - and still is - an NIH employee; as far as NIH is concerned, Hadley holds a position in the agency's science education office, a job she took after being forced to leave OSI.

Since that first summer morning,
Hadley has worked for Dingell essentially at his will; with a simple telephone request from his oversight and investigations subcommittee, she switches from the Executive branch to the Legislative branch for a day. For Dingell, Hadley is a fortunate windfall: a scientific misconduct expert whose views are in conflict with those of NIH director Bernadine Healy. Since one of Dingell's chief targets is OSI itself (he believes the office is vulnerable to conflicts of interest under NIH control), its former deputy director is an invaluable witness for the prosecution - or a prosecutor herself.

For NIH, however, it is a more questionable call. When Dingell requested the services of Walter Stewart, an NIH scientist who has made a career as a freelance fraud-buster, NIH essentially transferred him to the subcommittee for most of a year, a not uncommon process in which federal employees are temporarily 'detailed' to Congress. Hadley, however, has not been detailed. She remains on the $\mathrm{NIH}$ payroll, even when she is investigating the very agency that employs her, an apparent violation of the separation of powers between the branches of government required by the US Constitution.

NIH spokesman Don Ralbovsky says that Hadley is being made available to Dingell "primarily to answer questions". After several months of ad hoc arrangements, NIH and Dingell exchanged letters of agreement on Hadley's role last month, he says. In a statement released early this week, NIH stated that it had not been "aware that Dr Hadley was to participate in an interview of a [Public Health Service] employee being conducted by the subcommittee, nor had Dr Hadley been authorized to participate in any such interview." NIH policy is that it is not appropriate for NIH employees to "reveal or discuss without authorization confidential information obtained in the course of their current or previous duties," according to the statement. Hadley, NIH said, has "recently been reminded" of the policy.
Christopher Anderson 